\title{
Potential of Polyisoprenoid of Mangroves as Antimicrobial and Anticancer: A Bibliometric Analysis
}

\author{
Sumardi ${ }^{1,2}$, Masfria $^{2}$, Mohammad Basyuni $^{3 *}$, Abdi Wira Septama ${ }^{4}$ \\ ${ }^{1}$ Faculty of Pharmacy, Universitas Tjut Nyak Dhien, Medan, 20123, Indonesia \\ ${ }^{2}$ Faculty of Pharmacy, Universitas Sumatera Utara, Medan, 20155, Indonesia \\ ${ }^{3}$ Departement of Forestry, Faculty of Forestry, Universitas Sumatera Utara, Medan, 20155, Indonesia \\ ${ }^{4}$ Research Center for Chemistry, Indonesian Institute of Sciences, Banten, 15314, Indonesia \\ ${ }^{*}$ Corresponding Author e-mail: m.basyuni@usu.ac.id
}

\begin{abstract}
Mangroves are plants that hope to inhibit coastal abrasion because they can adapt to seawater and withstand beach posture. Polyisoprenoid compounds contained in mangroves have been known to have an important role in the process of adaptation to seawater salt stress. Publications in the Scopus database were collected using the keywords mangrove, polyisoprenoid, polyisoprene, and dolichol until December 2021. The articles obtained were analyzed bibliometrically using VOSviewer. Totally 129,406 documents were collected with the dominant topics apoptosis and antibacterial activity. Polyisoprenoid appeared 9 times with relevance values 1.1. Polyprenol and dolichol did not link with antibacterial, anticancer, or other biological activities. Several $106,679(82.5 \%)$ are original research articles, 13,907 (10.8\%) papers have been published this year (2021). English was mostly used in the language in the publication (95.5\%). The countries with the largest publications were the United States, then China, India, Australia, Brazil, United Kingdom, Germany, Japan, France, and Indonesia. The Marine Pollution Bulletin was the most publisher 1,875 documents. Four of the top ten funding sponsors are from China. Wang YS was the main collaborator who has publication links with 50 authors with a total link strength of 32 . The field of studies is still in the biological, environmental, social, and pharmaceutical sciences. The study of mangroves and polyisoprenoids related to antimicrobial assays and anticancer increases over time and still needs a lot of scientific studies. Greater research collaboration involving more authors were the hope until the clinic stage.
\end{abstract}

\section{Keywords}

Mangrove, Polyisoprenoid, Polyprenol, Dolichol, Antibacterial, Anticancer

Received: 12 September 2021, Accepted: 22 January 2022

https://doi.org/10.26554/sti.2022.7.1.22-28

\section{INTRODUCTION}

Mangroves grow widely in the tropics and subtropics, are distributed $75 \%$ in 15 countries and $22.6 \%$ in Indonesia (Giri et al., 2011). They play a role in the community's socio-economic development, especially in the Sumatra Utara regency. Firewood and charcoal are some of its products; besides, they were also used to treat the communities (Bandaranayake, 1998).

Polyisoprenoid has an essential role in living things, including in mangroves closely related to biosynthesis of isoprenoid secondary metabolites. Triterpenoid and phytosterol compounds are the most numerous (Skorupinska-Tudek et al., 2008; Inafuku et al., 2018). Polyisoprenoid content in mangroves generally into dolichol and polyprenol (Basyuni et al., 2018; Basyuni et al., 2017). The general structure of this compound was composed of isoprenoid isomers with a long number of carbon chains. Polyisoprenoid members consist of polyprenol, dolichol, and bombiprenon (Figure 4). The yield of polyisoprenoid from mangrove leaves growing on the coast of Langkat Regency, North Sumatra, Indonesia is shown in Table 3.

The articles include study mangroves related chemical content, role in biosynthesis and biological activity have reached more than hundreds of thousands of documents in the Scopus database and more than 6 million documents in the Google Engine database. Knowledge of the role of mangroves in human life needs to be explored, especially in solving problems of infection and cancer, still the main issues in the world.

The bibliometric method is a systematic literature review method that can be used to analyze scientific articles with specific topics with mathematical calculations (Chen et al., 2014). This method can assess the quality of a study, analyze critical areas of researches, and predict the future. Scopus online database contains almost all important global articles and 


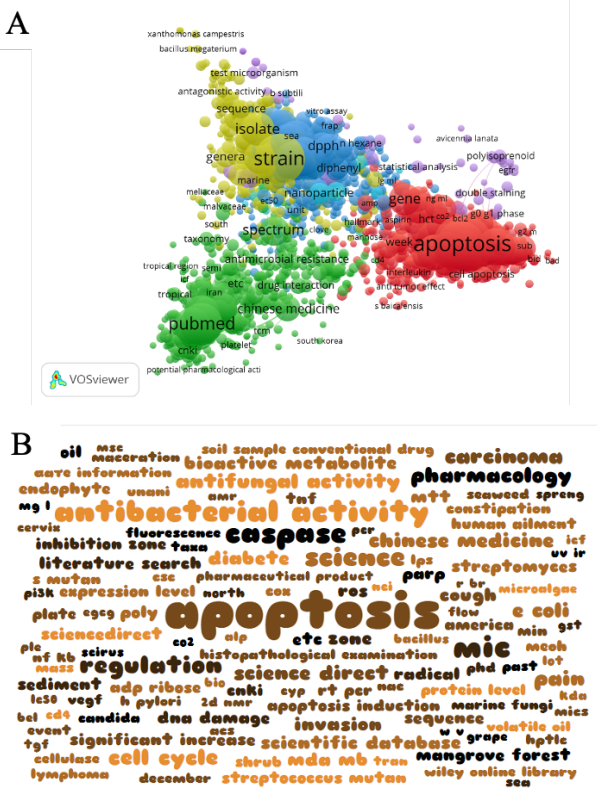

Figure 1. Bibliometric Analysis of The Keywords in Publication of Mangrove; Polyisoprenoid; Polyprenol; Dolichol. (A) Co-Occurance of Keyword. The Size of The Node Indicated The Frequency with which The Keyword Appeared. A Shorter Distance Indicates a Greater Amount of Co-Occurrence Between Two Keywords. (B) Word Cloud Consisted of 1943 Keywords that Appear with a Frequency of 3 or More Times. The Text Size Indicated The Repetition frequency.

has analysis tools to produce representative graphs. Furthermore, the export results are analyzed using software, including VOSviewer.

Currently, no bibliometric analysis of the role of mangroves as an antimicrobial and anticancer has been carried out, till now. More comprehensive information based on literature will provide benefits to the community. Therefore, our study was performed to understand potential mangroves, polyisoprenoid, polyprenol, and dolichol as antibacterial and anticancer.

\section{EXPERIMENTAL SECTION}

\subsection{Methods}

Global library of mangroves, polyisoprenoids, polyprenols, and dolichol detected in the Scopus database on 25 November 2021. The keywords used in the search field include "mangroves" or "polyisoprenoid" or "polyprenol" or "dolichol". The information extracted for the year of publication, language, journal, author, affiliation, keywords, document type, abstract, and the number cited convert to CSV and RIS extension. VOSviewer application version 1.6.17 is used to analyze co-authorship, co-occurrence, citation, bibliographic coupling, co-citation, and themes. The distance attribute of each value is used to assess the "link" and "total link strength" attributes (Jalal, 2019).

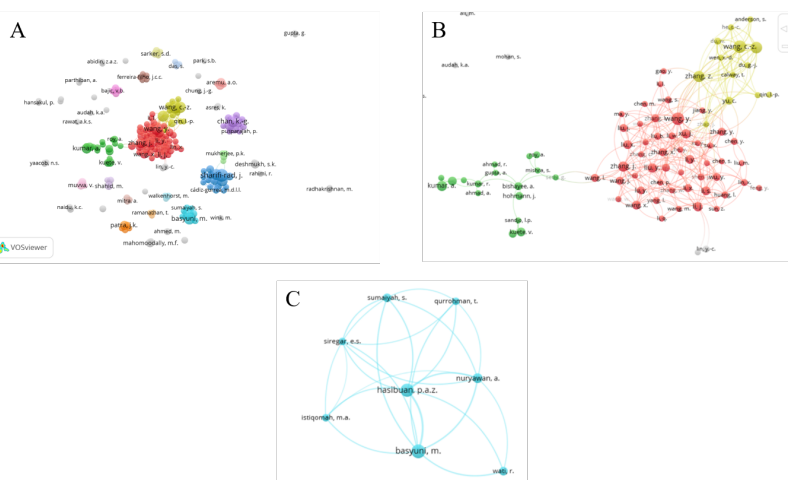

Figure 2. Bibliometric Analysis of Co-Authorship. (A) Citations of Authors. Fouthy Four Clusters were Shown in Different Colors. Top Six Cluster with The Largest Number of Authors. (B) Wang Y is The Most Collaborator with Purple Cluster Color. (C) Eight Authors from Indonesia Who have Relationship Publications.

\section{RESULT AND DISCUSSION}

\subsection{Publication Yield in Bibliometric Analysis}

Total of 129,342 documents related to the topic of mangroves" or "polyisoprenoid" or "polyprenol" or "dolichol were identified in the Scopus database. $106,679(82.5 \%)$ original research articles, 9,646 (7.5\%) review articles, 5,504 (4.3\%) conference papers, 5,176 (4.0\%) book chapters, $877(0.7 \%)$ books, 424 $(0.3 \%)$ note, $288(0.2 \%)$ editorial and 748 other publications including short survey, letter, erratum, conference review, data paper, retracted, abstract report, etc.

The publications detected in the 1846-2022 range show $410(0.3 \%)$ papers published in 2022. Papers, $13,907(10.8 \%)$ have been published this year (2021), and 12,451 (9.6\%) articles were published in 2020 , while lower years have a minor trend. The increasing trend indicates that research was intensive and diverse globally.

The six official languages of the United Nations are Arabic, Chinese, English, French, Russian and Spanish. English is the most widely used language globally, including the Scopus database. This language dominated $12.4129(95.5 \%)$ and followed by Chinese, Spanish, Portuguese, French, Japanese, German, Russian, Korean, Persian, Turkish, Polish, Italian, Malay, Czech, Arabic, Croatian, Thai, Lithuanian, Hungarian, Swedish, Ukrainian, Bulgarian, Indonesian, Serbian, and Slovak (Table 1).

Based on the stages, the papers classified 128,063 (99\%) in final articles, while $1,279(1 \%)$ articles in press. These articles collected were dominantly published documents that have gone through the review process, while a small portion has a scheduled launch.

\subsection{The Keywords in Bibliometric Analysis}

The keyword used by the author in the search in the articles was set to a threshold of 3 times from the Scopus database 

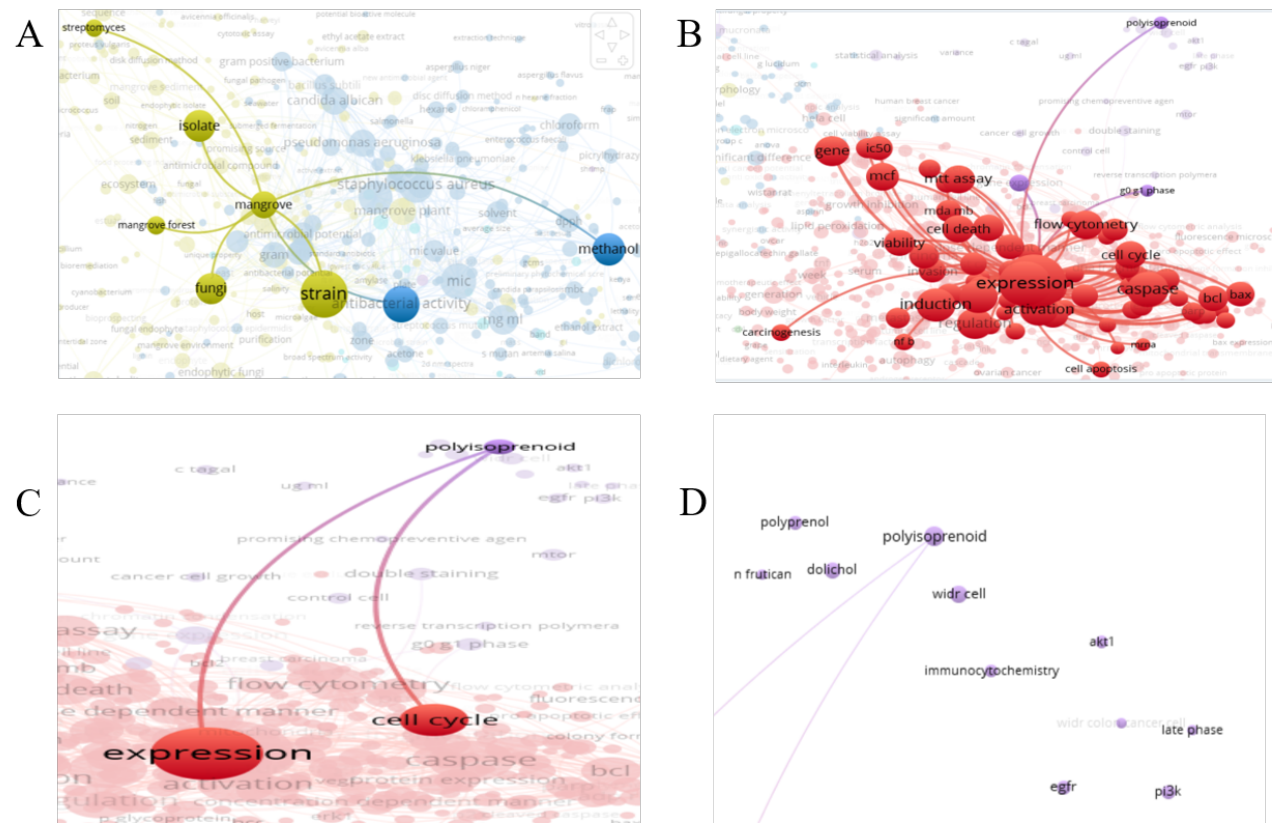

Figure 3. (A) Keyword Mangrove with Total Link Strength 599 and Related Antibacterial Activity and Fungal Assay. (B) Term of Expression in Molecule, Gen, and Cycle Cells Linked to Polyisoprenoid. (C) Occurrence of Polyisoprenoid was Nine with Total Link Strength 198. Related Keywords were Expression and Cell Cycle

in the form of RIS extension. A total of 27,293 keywords appeared 3,238 times. The most frequently occurring keyword was apoptosis (198 times and relevance score 0.56), followed by antibacterial activity, phytochemistry, mangrove plant, cell death, etc. (Figure 1A). While polyisoprenoid has frequency 9 and relevance score 1.1 (Figure 3C). Meanwhile, polyprenol and dolichol have occurrences of 5 and 6 times but still have a small link value and frequency.

The graphic of word cloud showed the largest keyword size was apoptosis followed by antibacterial activity, antifungal activity, diabetes, and carcinoma, but the difference in frequency was not significant (Figure 1B).

\subsection{Bibliometric Analysis of The Publication}

The largest number of published articles has been grouped by country, language, funding sponsor, subject area, affiliation, source title, and author name showed Table 1. The majority of the studies were biological, environmental, social, and pharmaceutical sciences, focusing on the study of apoptosis, antibacterial, antifungal, and pharmacological activities. Investigations leading to clinical science have not been a concern yet.

The country that has the largest publication was the United States, followed by China, India, Australia, Brazil, United Kingdom, Germany, Japan, France, and Indonesia, with the majority of language usage being English, while the largest publisher was the Chinese Academy of Science (5223) even most of the affiliate comes from China.

The Marine Pollution Bulletin published 1,875 publications with CiteScore: 7.9 SJR: 1,548 SNIP: 1,566 in 2020. In addition, there were also more than a thousand articles published by Science of The Total Environment (CiteScore: 10.5 SJR: 1,795 SNIP: 2,015), Estuarine Coastal and Shelf Science (CiteScore 4.6 SJR: 0.852 SNIP: 1.135), Plos One (CiteScore: 5.3 SJR: 0.99 SNIP: 1.349), IOP Conference Series Earth and Environmental Science (CiteScore: 0.5 SJR: 0.179 SNIP: 0.436) and Marine Ecology Progress Series (CiteScore: 4.4 SJR: 1.151 SNIP: 0.958).

The citescore value, scimago journal range (SJR), Source Normalized Impact per Paper (SNIP) is the value calculated from the number of publications, the frequency of citations per paper, and subject area so that it can be used as a parameter for the quality of a publisher or article.

More than eighty percent of publications scientific articles with the top ten funding and publication of articles in the Scopus database was the National Natural Science Foundation of China with more than ten thousand articles (Table 1).

Hyde Kevin D from Mae Fah Luang University, Chiang Rai, Thailand was the most prominent author with 317 publications and has been cited as many as 51,152 times, followed Tam, Lovelock, Dahdouh-Guebas, F, Duarte, Basyuni, Connolly, Proksch, Proksch, Kathiresan, and Gu have publications, respectively $217 ; 187 ; 166 ; 162 ; 159 ; 158 ; 158 ; 146 ; 145$ documents (Table 1).

\subsection{Analysis of Co-Authorship}

There were 5,790 authors who participated in the publication of mangroves, polyisoprenoids, polyprenols, and polyprenols. In this analysis, the authors filtered at least three published documents. A total of 199 authors were selected to measure 
Table 1. Top Ten Countries, Languages, Organizations, Funding Sponsors, Source Title, Document Type, Subject Area, Author Name with Publications Related to Mangroves, Polyisoprenoid, Polyprenol, and Dolichol

\begin{tabular}{|c|c|c|c|}
\hline Subject & Number of Publication & Subject & Number of Publication \\
\hline Countries & & Affiliation & \\
\hline United States & 25659 & Chinese Academy of Sciences & 5223 \\
\hline China & 23064 & Ministry of Education China & 3317 \\
\hline India & 12698 & $\begin{array}{l}\text { University of Chinese Academy of } \\
\text { Sciences }\end{array}$ & 1968 \\
\hline Australia & 9964 & $\begin{array}{l}\text { CNRS Centre National de la } \\
\text { Recherche Scientifique }\end{array}$ & 1798 \\
\hline Brazil & 7993 & Universidade de São Paulo & 1457 \\
\hline United Kingdom & 7777 & The University of Queensland & 1278 \\
\hline Germany & 6527 & Sun Yat-Sen University & 1184 \\
\hline Japan & 5670 & James Cook University & 1104 \\
\hline France & 5193 & Xiamen University & 1049 \\
\hline Indonesia & 4366 & Ocean University of China & 980 \\
\hline Language & & Source Title & \\
\hline English & 124129 & Marine Pollution Bulletin & 1875 \\
\hline Chinese & 2872 & $\begin{array}{l}\text { Science Of The Total Environ- } \\
\text { ment }\end{array}$ & 1579 \\
\hline Spanish & 1072 & $\begin{array}{l}\text { Estuarine Coastal And Shelf Sci- } \\
\text { ence }\end{array}$ & 1465 \\
\hline Portuguese & 785 & Plos One & 1272 \\
\hline French & 447 & $\begin{array}{l}\text { Iop Conference Series Earth And } \\
\text { Environmental Science }\end{array}$ & 1221 \\
\hline Japanese & 148 & Marine Ecology Progress Series & 1057 \\
\hline German & 131 & $\begin{array}{l}\text { Environmental Science And Pol- } \\
\text { lution Research }\end{array}$ & 956 \\
\hline Russian & 100 & Remote Sensing & 888 \\
\hline Korean & 58 & Scientific Reports & 737 \\
\hline Persian & 35 & Hydrobiologia & 716 \\
\hline Funding Sponsor & & Document Type & \\
\hline $\begin{array}{l}\text { National Natural Science Founda- } \\
\text { tion of China }\end{array}$ & 10413 & Article & 106679 \\
\hline National Science Foundation & 3565 & Review & 9646 \\
\hline $\begin{array}{l}\text { Conselho Nacional de Desenvolvi- } \\
\text { mento Científico e Tecnológico }\end{array}$ & 2594 & Conference Paper & 5504 \\
\hline $\begin{array}{l}\text { Coordenação de Aperfeiçoamento } \\
\text { de Pessoal de Nível Superior }\end{array}$ & 1857 & Book Chapter & 5176 \\
\hline $\begin{array}{l}\text { National Key Research and Devel- } \\
\text { opment Program of China }\end{array}$ & 1823 & Book & 877 \\
\hline $\begin{array}{l}\text { Ministry of Science and Technol- } \\
\text { ogy of the People's Republic of } \\
\text { China }\end{array}$ & 1557 & Note & 424 \\
\hline Chinese Academy of Sciences & 1546 & Editorial & 288 \\
\hline National Institutes of Health & 1539 & Short Survey & 258 \\
\hline $\begin{array}{l}\text { Japan Society for the Promotion } \\
\text { of Science }\end{array}$ & 1430 & Letter & 215 \\
\hline $\begin{array}{l}\text { Minist } \tilde{A} @ \text { rio da Ciẽ }{ }^{a} \text { ncia, Tec- } \\
\text { nologia e Inova } \tilde{\AA} \S \tilde{A} £ o\end{array}$ & 1316 & Erratum & 105 \\
\hline Subject Area & & Author Name & \\
\hline $\begin{array}{l}\text { Agricultural and Biological Sci- } \\
\text { ences }\end{array}$ & 59690 & Hyde, K.D. & 317 \\
\hline Environmental Science & 45174 & Tam, N.F.Y. & 207 \\
\hline $\begin{array}{l}\text { Biochemistry, Genetics and } \\
\text { Molecular Biology }\end{array}$ & 25359 & Lovelock, C.E. & 187 \\
\hline Earth and Planetary Sciences & 24631 & Dahdouh-Guebas, F. & 166 \\
\hline Chemistry & 9653 & Duarte, C.M. & 162 \\
\hline Immunology and Microbiology & 8979 & Basyuni, M. & 159 \\
\hline Medicine & 8521 & Connolly, R.M. & 158 \\
\hline $\begin{array}{l}\text { Pharmacology, Toxicology and } \\
\text { Pharmaceutics }\end{array}$ & 7477 & Proksch, P. & 158 \\
\hline Social Sciences & 7013 & Kathiresan, K. & 146 \\
\hline Engineering & 6593 & Gu, J.D. & 145 \\
\hline \multicolumn{4}{|l|}{ Year } \\
\hline 2021 & 13907 & & \\
\hline 2020 & 12451 & & \\
\hline 2019 & 10553 & & \\
\hline 2018 & 9730 & & \\
\hline 2017 & 8299 & & \\
\hline 2016 & 7683 & & \\
\hline 2015 & 6917 & & \\
\hline 2014 & 6325 & & \\
\hline 2013 & 5848 & & \\
\hline 2012 & 5271 & & \\
\hline
\end{tabular}


Table 2. Biological Activities of Polyisoprenoid

\begin{tabular}{|c|c|c|c|c|}
\hline Species & $\begin{array}{l}\text { IC }_{50} \text { viability WiDr } \\
\text { Cell }(\mu \mathrm{g} / \mathrm{mL})\end{array}$ & $\begin{array}{l}\mathrm{IC}_{50} \text { scavenging } \\
\text { DPPH }\end{array}$ & $\begin{array}{l}\text { Inhibition } \\
\text { growth of E. coli } \\
(\mathrm{mm})\end{array}$ & $\begin{array}{l}\text { Inhibition } \\
\text { growth of } \\
\text { S. aureus } \\
(\mathrm{mm})\end{array}$ \\
\hline Acacia auriculiformis & $1,425.46$ & 17,100 & 13.17 & 12.29 \\
\hline Acrostichum aureum & 314.623 & nt & nt & nt \\
\hline Avicennia lanata & 305.928 & 14,681 & 10.19 & 13.25 \\
\hline Avicennia marina & 209.693 & 13,561 & 10.85 & 10.52 \\
\hline Avicennia officinalis & $1,444.45$ & 4,515 & 12.66 & 8.85 \\
\hline Avicennia alba & $\mathrm{nt}$ & 12,250 & na & 9.24 \\
\hline Barringtonia asiatica & $1,831.74$ & 4,427 & 12.83 & 9.6 \\
\hline Bruguiera gymnorrhiza & 350.395 & nc & 10.16 & 11.645 \\
\hline Bruguiera gymnorrhiza yellow leaf & $1,853.57$ & nt & nt & $\mathrm{nt}$ \\
\hline Calophyllum inophyllum & 275.829 & 1,463 & 9.65 & 8.66 \\
\hline Ceriops tagal & 276.055 & 5,680 & 9.14 & 13.48 \\
\hline Hibiscus tiliaceus & 409.821 & 2,018 & 10.52 & 11.57 \\
\hline Nypa fruticans & 180.186 & 2,438 & 14.48 & 11.66 \\
\hline Pandanus odoratissimus & 513.598 & nc & 12.49 & 12.38 \\
\hline Pongamia pinnata & 386.77 & 5,100 & 10.19 & 10.96 \\
\hline Rhizophora mucronata & 278.335 & 9,195 & na & 11.09 \\
\hline Ricinus communis & $1,890.00$ & 27,620 & 10.16 & 8.23 \\
\hline Stachytarpheta jamaicensis & 285.492 & 971 & 9.99 & 11.35 \\
\hline
\end{tabular}
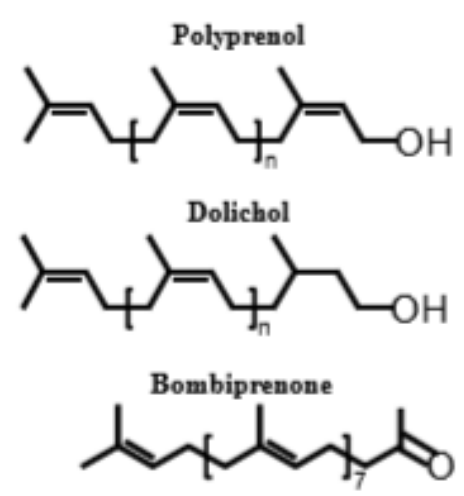

Figure 4. Isoprenoid Composed Polyisoprenoid Compounds (Basyuni et al., 2018)

total link strength. The six most significant clusters of total authors can be categorized as having total links. The first cluster consisted of 50 authors, with the main collaborator was Wang, the total link strength 32 . The second cluster consisted of 17 authors; Kumar has the most links. The third cluster consisted of 16 authors as the most collaborators on SharifiRad. The fourth cluster consists of 13 authors as the most collaborators on Wang and Yuan. The fifth cluster consists of 11 authors, with Chan and Lee as main collaborators. Besides that, the sixth cluster consists of 8 authors and Basyuni $\mathrm{M}$ as the main collaborator, with the affiliation from North Sumatra University.

The participative of researchers, official institutions, coun-
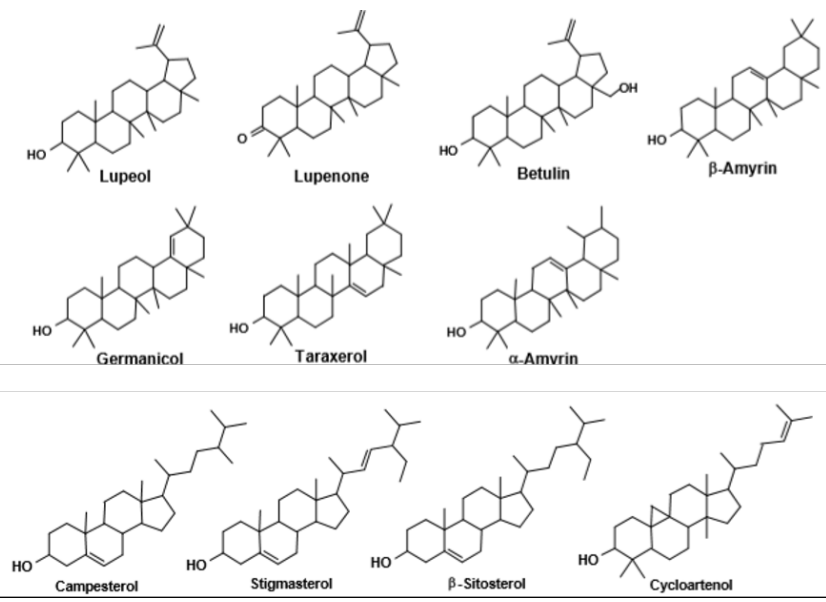

Figure 5. Phytomedicine Content of The Leaves and Roots of Some Mangroves (Basyuni et al., 2017)

tries, and collaborative funding will benefit the global community. The scientific studies were used for nature and maintaining its sustainability.

\subsection{Anticancer Activity of Polyisoprenoid}

At least ten mangrove species have known polyisoprenoid activity on WiDr cancer cell culture. Polyisoprenoid with predominant dolichol from Avicennia marina has toxicity properties with a value $\mathrm{IC}_{50} 155 \mu \mathrm{g} / \mathrm{mL}$ against colon cancer cells with a selective index 5.2. In the cell cycle, the dominant polyisoprenoid suppresses the G0-G1 phase. Analysis using flowcytometry showed apoptotic induction by increasing expression p52 and gen Bcl-2. COX-2 gene expression can be suppressed directly 
Table 3. The Yield of Polyisoprenoid from Mangrove Leaves

\begin{tabular}{ccc}
\hline Species & $\begin{array}{c}\text { Polyisoprenoid } \\
(\mathrm{mg} / \mathrm{gdw})\end{array}$ & $\begin{array}{c}\text { Yield } \\
(\%)\end{array}$ \\
\hline A. auriculiformis & 28 & 2.8 \\
B. asiatica & 133 & 13 \\
C. equisatifolia & 65 & 6.5 \\
C. inophyllum & 25 & 2.5 \\
H. tiliaceus & 14 & 1.4 \\
M. candidum & 140 & 14 \\
M. citrifolia & 119 & 12 \\
P. odoratatissima & 23 & 2.3 \\
P. pinnata & 12 & 1.2 \\
R. communis & 20 & 2 \\
S. hydrophyllacea & 138 & 13.8 \\
S. jamaicensis & 19 & 1.9 \\
S. portulacastrum & 53 & 5.3 \\
T. catappa & 65 & 6.5 \\
\hline
\end{tabular}

proportional to increased doses (Illian et al., 2018; Sari et al., 2018a; Sari et al., 2018b; Sari et al., 2018c). It can still be considered as an anticancer or complementary candidate. The methanol, water, and n-hexane extract of leaves have effective cytotoxic against HL-60, HCT-116, and NCI-H23 cells besides inhibiting antiproliferative HepG2 and MCF-7 cell culture (Albinhassan et al., 2021; Reddy and Ratna, 2016).

Dolichol from Avicennia lanata has $\mathrm{IC}_{50} 306 \mu \mathrm{g} / \mathrm{mL}$ for colon cancer cells with selective index 1.9. The cell cycle did not indicate suppressive activity and was lower than Avicennia marina.

Polyisoprenoid from Rhizophora mucronata and Ceriops tagal had toxic on WiDr cell cultures with $\mathrm{IC}_{50} 278$ and $276 \mu \mathrm{g} / \mathrm{mL}$, respectively. The compounds inhibit the cell cycle in the $\mathrm{S}$ and G2/M phases; besides that expressed Bcl-2 and cyclin D1 genes were suppressed (Sari et al., 2018c). Nypa fruticans showed the highest cytotoxic activity and moderate category with $\mathrm{IC}_{50} 180.186 \mu \mathrm{g} / \mathrm{mL}$. WiDr cell culture, this compound inhibits the cell cycle in S and G2/M phase (Sari et al., 2018b).

\subsection{Antimicrobial Activity of Polyisoprenoid}

Sixteen mangrove species with varying polyisoprenoids have obtained twelve as antibacterial potential, following Acacia auriculiformis, Avicennia lanata, Avicennia marina, Avicennia officinalis, Barringtonia asiatica, Bruguiera gymnorrhiza, calophyllum inophyllum, Hibiscus tiliaceus, Nypa fruticans, Pandanus odoratissimus, Pongamia pinnata, and Ricinus communis, shown on Table 2.

The polar portion of mangroves was reported to act as antibacterial. They were Avicennia marina, Acacia auriculiformis, Barringtonia asiatica, Hibiscus tiliaceus, Bruguiera gymborhiza, Avicennia lanata, Avicennia offcinalis, Avicennia alba, Pandanus odoratissimus, Ricinus communis (Gurmeet and Amrita, 2015; Khan and Omoloso, 2002; Mandal et al., 2005; Manilal et al., 2016; Naz and Bano, 2012; Thatoi et al., 2016). Further develop- ment of studies related to mechanical action and safety was still needed to find out active compounds that can be used as biomarkers.

Analysis of the chemical content of the non-polar parts of the leaves and roots of six mangroves, Acanthus ilicifolius (Acanthaceae), Bruguiera parviflora (Rhizophoraceae), Ceriops tagal (Rhizophoraceae), Rhizophora apiculata (Rhizophoraceae), Sonneratia caseolaris (Sonneratiaceae), and Xylocarpus granatum (Meliaceae), by using GC-MS analysis the chemical information has been obtained. Namely: lupeol, lupenone, betulin, $\beta$-amyrin, germanicol, taraxerol, $\alpha$-amyrin, campesterol, stigmasterol, $\beta$-sitosterol, and cycloartenol, as shown in Figure 5 .

\section{CONCLUSION}

Mangroves are potential plants that grow along the coastline and provide benefits in aspect of life. Publication of academic documents on mangroves regarding biological content and activity continues to increase, and there is even a publication plot in 2022. Evaluation of specific and in-depth topics from scientific articles on mangroves is still much needed in developing and resolving global health problems. Research in microbiology and cancer still has an excellent opportunity to be explored and requires collaboration with authors with various disciplines.

\section{ACKNOWLEDGEMENT}

This work was supported financially by the Ministry of Research, Technology, and Higher Education of the Republic of Indonesia through collaborative research between universities (PKPT) 2019 (No. 017/K1.1/V/2019).

\section{REFERENCES}

Albinhassan, T. H., K. A. Saleh, Z. Barhoumi, M. A. Alshehri, A. M. Al-Ghazzawi, et al. (2021). Anticancer, AntiProliferative Activity of Avicennia Marina Plant Extracts. Journal of Cancer Research and Therapeutics, 17(4); 879

Bandaranayake, W. (1998). Traditional and Medicinal uses of Mangroves. Mangroves and Salt Marshes, 2(3); 133-148

Basyuni, M., H. Sagami, S. Baba, H. Oku, et al. (2017). Distribution, Occurrence, and Cluster Analysis of New Polyprenyl Acetones and Other Polyisoprenoids from North Sumatran Mangroves. Dendrobiology, 78(18-31)

Basyuni, M., R. Wati, H. Sagami, S. Sumardi, S. Baba, and H. Oku (2018). Diversity and Abundance of Polyisoprenoid Composition in Coastal Plant Species from North Sumatra, Indonesia. Biodiversitas Journal of Biological Diversity, 19(1); $1-11$

Chen, C., R. Dubin, and M. C. Kim (2014). Emerging Trends and New Developments in Regenerative Medicine: A Scientometric Update (2000-2014). Expert Opinion on Biological Therapy, 14(9); 1295-1317

Giri, C., E. Ochieng, L. L. Tieszen, Z. Zhu, A. Singh, T. Loveland, J. Masek, and N. Duke (2011). Status and Distribution 
of Mangrove Forests of The World Using Earth Observation Satellite Data. Global Ecology and Biogeography, 20(1); $154-159$

Gurmeet, S. and P. Amrita (2015). Unique Pandanus-Flavour, Food and Medicine. Journal of Pharmacognosy and Phytochemistry, 5(3); 08-14

Illian, D. N., M. Basyuni, R. Wati, P. A. Z. Hasibuan, et al. (2018). Polyisoprenoids from Avicennia Marina and Avicennia Lanata Inhibit WiDr Cells Proliferation. Pharmacognosy Magazine, 14(58); 513

Inafuku, M., M. Basyuni, and H. Oku (2018). Triterpenoid Modulates The Salt Tolerance of Lanosterol Synthase Deficient Saccharomyces Cerevisiae, GIL77. Saudi Journal of Biological Sciences, 25(1); 1-9

Jalal, S. K. (2019). Co-authorship and Co-occurrences Analysis Using Bibliometrix R-Package: A Casestudy of India and Bangladesh. Annals of Library and Information Studies (ALIS), 66(2); 57-64

Khan, M. and A. Omoloso (2002). Antibacterial, Antifungal Activities of Barringtonia Asiatica. Fitoterapia, 73(3); 255260

Mandal, P., S. S. Babu, and N. Mandal (2005). Antimicrobial Activity of Saponins from Acacia Auriculiformis. Fitoterapia, 76(5); 462-465

Manilal, A., T. Tsalla, Z. Zerdo, G. Ameya, B. Merdekios, and S. E. John (2016). Evaluating The Antibacterial and Anticandidal Potency of Mangrove, Avicennia Marina. Asian Pacific Journal of Tropical Disease, 6(2); 136-140

Naz, R. and A. Bano (2012). Antimicrobial Potential of Ricinus Communis Leaf Extracts in Different Solvents Against Pathogenic Bacterial and Fungal Strains. Asian Pacific Journal of Tropical Biomedicine, 2(12); 944-947

Reddy, A. and G. Ratna (2016). Evaluation of In Vitro Anticancer Activity of Selected Mangrove Plant Extracts Against MCF7 Cell Line. International Journal of Recent Scientific Research, 7(6); 12315-8

Sari, D. P., M. Basyuni, P. A. Hasibuan, S. Sumardi, A. Nuryawan, and R. Wati (2018a). Cytotoxic and Antiproliferative Activity of Polyisoprenoids in Seventeen Mangroves Species Against WiDr Colon Cancer Cells. Asian Pacific Journal of Cancer Prevention: APJCP, 19(12); 3393

Sari, D. P., M. Basyuni, P. A. Z. Hasibuan, and R. Wati (2018b). The Inhibition of Polyisoprenoids from Nypa Fruticans Leaves on Cyclooxygenase 2 Expression of WiDr Colon Cancer Cells. Asian Journal of Pharmaceutical and Clinical Research, 11(8); 156

Sari, D. P., M. Basyuni, P. A. Z. Hasibuan, R. Wati, et al. (2018c). Cytotoxic Effect of Polyisoprenoids from Rhizophora Mucronata and Ceriops Tagal Leaves Against WiDr Colon Cancer Cell Lines. Sains Malaysiana, 47(9); 19531959

Skorupinska-Tudek, K., J. Wojcik, and E. Swiezewska (2008). Polyisoprenoid Alcohols-Recent Results of Structural Studies. The Chemical Record, 8(1); 33-45

Sumardi, S., M. Bastuni, and R. Wati (2018). Antimicrobial Activity of Polyisoprenoids of Sixteen Mangrove Species from North Sumatra, Indonesia. Biodiversitas Journal of Biological Diversity, 19(4); 1243-1248

Thatoi, H., D. Samantaray, and S. K. Das (2016). The Genus Avicennia, a Pioneer Group of Dominant Mangrove Plant Species with Potential Medicinal Values: A Review. Frontiers in Life Science, 9(4); 267-291 